\title{
DLC膜の生体材料としての応用
}

\author{
平栗健二
}

(平成11年11月10日受理, 平成11年11月25日採択）

\section{Application of DLC Film to Biomaterials}

\begin{abstract}
Kenji Hirakuri
Diamond-like carbon (DLC) films have received much attention owing to their attractive properties which are close to those of diamond : extreme hardness, high thermal conductivity, abrasion resistance, corrosion resistance against chemicals, good biocompatibility and uniform flat surface. Furthermore, DLC films can be easily deposited on many substrates at room temperature. Due to their interesting advantages, DLC films have been developed for application as biomedical materials (e.g. coatings on contact lenses). In the presented study we have utilized DLC films as coatings of diaphragms (polyurethane) in artificial hearts.

For evaluation of the diffusion between the solutions (silicone oil and blood) a special two-chamber apparatus was developed. Physiological saline solution and distilled water were used for these experiments. In case of the uncoated polyurethane diaphragm diffusion of $\mathrm{Na}$ ions through the diaphragm leads to an enrichment (diffusion) of Na on the other side of the diaphragm at the ppm level. In case of DLC coated diaphragms such an enrichment could not be observed.

The Epifluorescent Video Microscopy (EVM) system measured the platelet adhesion on the DLC film surface, using whole human blood containing Mepacrine-labeled platelets perfused at a wall shear rate of $100 \mathrm{~s}^{-1}$ at 1 -min intervals for a period of $20 \mathrm{~min}$. Based on these results, it is recommended that for use in implantable blood contacting device as coat materials. This DLC appear to be promising candidate for biomaterials application and merit further investigation. Finally, it should be mentioned that these DLC films also show a good biocompatibility.
\end{abstract}

KEYWORDS : Diamond-like carbon, Biomaterial, Atomic force microscopy, Biocompatibility

\section{1. はじめに}

安定した構造の炭素材料は, 電力需要を賄う原子力発電や 最先端の通信機器などの広範井な分野へ活用されている112i。 高度な現代医療でも, 急速な工業技術力による開発が進み, 炭 素系材料の応用が飛躍的に発展している。これは, 新炭素材 の開発やその適用が, 医用材料（バイオマテリアル）の新た な展開を導き, 医用技術を増進させていくことに源を発して いる。すでに多くの炭素系材料（パイロライトカーボンが人 工弁として, 高分子ポリマーが人工血管として）が, 実用化さ れている3”。しかし，これらの素材は，単一の特異な特性をそ のまま利用する場合が多く, 数種の長所を活用した複合材の 開発には至っていない。

この理由は,これまでの材料開発が各分野の研究者独自の 領域で実施されており, 総合的な性能が要求されるバイオマ テリアル分野では困難さを伴ってきた。バイオマテリアルと して所望される機能を満足するには物理的, 化学的, 生物学的 な視点や生態組織との関係など複雑に絡み合った要求を同時
に実現する必要がある。具体的には,バイオマテリアルには， 強度や加工性能などのマクロ的な性質と生体や細胞との反応 などのミクロ的な性質を併せ持つ物質が望まれる訳である。 現時点でのバイオマテリアル材料としては高分子, 金属, セ ラミックス等が, それぞれの特長を生かしながら利用されて いる2)。高分子材料では, 塩化ビニール樹脂, ポリプロピレン, シリコーンなどが, 医用材料として種々の人工臓器（人工肺, 人工関節）に応用されている4)。合成高分子材料としてのポ リスチレン, ポリカーボネートは, 光学的に透明で機械的強度 が, ある程度得られることから人工心臓などに活用されてい る ${ }^{3)}$ 。これらの高分子材料は, 適度な変形を必要とする部位に 適し, 柔軟な材料である特徵を持っている。

金属材料としては純チタンが, 比較的生体との適合性が良い ことから強度に重点が置かれた部分に利用されている4)。最 近では, 耐食性に優れたステンレス鋼やコバルトクロム合金が 開発され, 整形外科や㐘科分野での利用が広まっている31。し かしながら, 各々の使用部分での生体適合性（抗血栓性, 溶血 性など）や耐久性などの諸特性において問題点を抱えながら 
使われているのが現状である2ね,3\%

セラミックス材料は, 酸化物として表面が安定であるため バイオマテリアルとして用いられている。素材強度も比較的 強靱であるので, 人工関節や歯科材料として利用頻度が离い。 しかし, セラミックス故の脆性が介在するので, その性質の改 善が望まれている。

これらの材料は, 各々の特長を独立で利用するべく使われ ており,相互の性質を補完し合うような複合材料の開発が待 たれている（一部では, シリコンカーバイトなどをコーティ ングする技術が開発されている)。つまり，ある種の材料は強 度的には優れているが, 生体表面との接触による異物反応が 引き起こされ，炎症や毒性などの反応が発生する場合があり， その反対の性質を持つ材料もある。

炭素 (カーボン) 系材料は, 古くから生体との反応性が低 くバイオマテリアルとしての新材料として期待されていた物 質である。工業材料である炭素系材料の研究開発の取り組み が進展し, 新しい製法の発見による新奇な構造を持つ物質の 生成やその物性の評価が進むと魅力的な新しい高機能炭素系 素材としてもてはやされるようになってきた。カーボン系材 料は, 主体として炭素元素から構成されており, 煤に代表され る黒鉛, 貴金属の代表格ダイヤモンド, 新展開が期待されてい るダイヤモンド状炭素（Diamond-like Carbon：DLC）膜, 特 殊な構造を持つフラーレンやカーボンナノチューブも包含し ている。このカーボン材料が, 医用分野での先端材料として 注目を集めている点は, 生体適合性に優れていて生体内での 反応が少なく, 体内においても安定して存在することとその 優れた物性を有することに大きな理由がある。DLC膜は, 極 表面へのコーティングが可能であることから,コーティング によりこれまで表面反応により利用が拒まれてきた高強度材 料を応用する可能性も拡大している。本説では, 近年その物 性に注目が集まっているDLC膜の生体材料としての応用の 可能性について概説する。

\section{DLC薄膜}

製造技術の発展やプロセスの制御性向上から, 現在も新素 材の開発や応用が飛躍的に進んでいる。有機, 無機を問わず, 炭素系材料でも新たな合成法の発明により, 特異な物性を持 つ材料の発見が続いている。無機材質研究所のグループによ る気相成長での人工ダイヤモンド合成法の実用的な開発は,

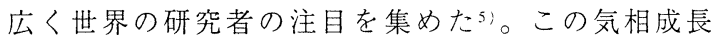
(Chemical Vapor Deposition：CVD）法は, 装置が安価で比較 的容易にダイヤモンド合成が可能であり，しかも膜状にある 種の基板上に成長可能な方法である。しかし, 気相成長ダイ ヤモンドは, 優れた特性（高硬度, 高抵抗率, 高熱伝導率, 高帯 域の光透過性等) を持つ一方で, 合成温度が $800^{\circ} \mathrm{C}$ 程度必要で あり,ささに合成面積が狭小に限定 $(30 \mathrm{~mm} \times 30 \mathrm{~mm}$ 程度 $)$ さ れることが応用性を妨げている。
一方, ダイヤモンドの特性に類似した炭素膜（いわゆる DLC膜：DLCの名前の由来は，性質の類似性による）が, 室 温で大面積に堆積できることから, CVDダイヤモンド以上に 魅力ある材料として期街されている67.7)。類似している特性 としては, 高硬度 $(\sim 50 \mathrm{GPa})$, 高抵抗率 $\left(\sim 10^{10} \Omega \mathrm{m}\right)$, 化学 的な薬品に対方方耐食性, 広带域の光透過性 $(\sim 300 \mathrm{~nm})$ 等 である7!。これらの特長に加え, 低摩擦係数, しゅう動性等の 性質を有する。

DLC膜の棈造については, 結晶性ではなくアモルファスで あることが透過電子顕微鏡の分析結果から判明している。膜 中には，炭素の $\mathrm{sp}^{2} お よ ひ ゙ \mathrm{sp}^{3}$ 成分が混在しており，全体的に非 晶質 (アモルファス) 状である（一部, 微結晶を含むものも ある)。条件によっては, 数\%～数十\%の水素を含有している 膜も得られる。この混成軌道の割合が, DLC膜の物性值を大 きく左右していて, $\mathrm{sp}^{3} / \mathrm{sp}^{2}$ の成分比が, 硬度等の物性の変化に 強く起因している報告がある8”。このアモルファス構造から， 大面積化と表面平滑性の利点を生み出している。

DLC膜は, 多方面（電子工学, 機械工学, 医用工学, 光丁学分 野) への利用が期待され, 電気的絶縁材, 切削 · 加工工具, 光 学部材, トライボロジー部品として試作され, 一部の分野では すでに実用化されている。摩擦洔の劣化減少のため, 磁気テ ープやハードディスクの駆動部にDLCコーティングが施さ れ，その性能向上に一役を担っている9)。機械しゅう動部への 応用は, 家庭用混合水检に利用されているアルミナ上にDLC をコーティングし, 摩擦係数を低減することで, 機能性を高 め, 付加価值を向上させている ${ }^{10)}$ 。医用分野では, 紫外線を遮 り, 人の水晶体に近い光吸収性を持つことや水晶体上皮細胞 と接触しても炎症や混濁が生じない高品質眼内レンズとして DLCコーティングが提案された11。これらの研究と並行して 強酸や強アルカリ溶液に浸透した実験から, DLC膜の薬品に 対する耐食性が証明されている12)。この薬品に対する結果は, 部位によって $\mathrm{pH}$ 值が大きく異なる生体内での新しい材料と して, 大きな可能性を秘めている。他方, エネルギーや情報通 信, 航空, 宇宙の分野への応用も着々と進んでいる。

一般にダイヤモンドの物性に近い特性を一つ（通常は高硬 度）でも有する炭素膜をDLC膜と呼ぶが, DLC膜は, 作製方法 や作製条件によって得られる膜の特性が大きく異なり, 目的 に合った手法が選択されている(3)。以下にその概略を示す。

平行平板型高周波プラズマCVD法は, DLC膜作製の最もポ ピュラーな方法である6 (Fig.1)。原料となる炭化水素系ガス (一般的にメタンガス) を電源から供給される電力でプラズ マ分解し, 目的のDLC膜を基板となる母材上に堆積する。プ ラズマ生成用の電源周波数は, 通常電波法によって規定され た13.56MHzを用いる。本方法は, 比較的大規模のプラズマを 生成することができるので, 大面積母材へのコーティングが 可能である。高周波龙利用するので絶縁性や導電性母材など 電気的性質に対して材料を特定しない。この方法における 


\section{Vacuum chamber}

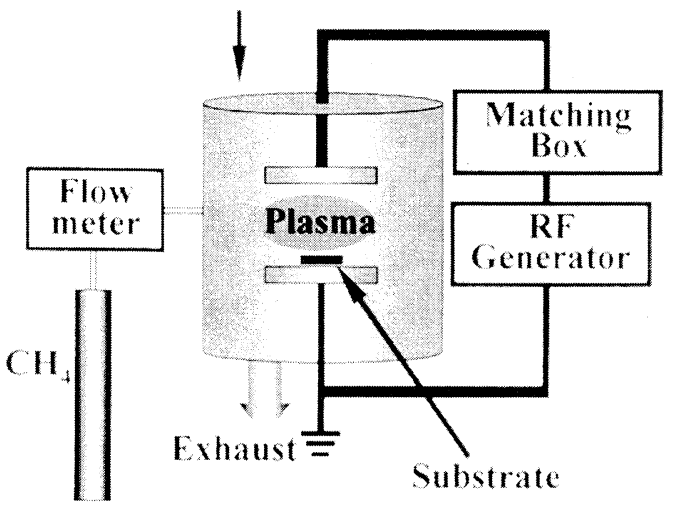

Fig.1 Schematic diagram of the experimental set-up for the deposition of DLC films.

DLC膜の特性を大きく左右する作製条件は, 膜作製時の圧力 で, 低い圧力条件で硬質なDLC膜が合成できる。压力を高く するとポリマー状の軟質な炭素膜となる7。これは, プラズマ 発生時に電極上に生まれる直流バイアス電圧が要因であると 考えられている8)。

イオンビーム法は, イオンを直接基板上に照射するので, 基 板は導電性の材料が巽択される。イオンビーム法の原料ガス は, 炭化水素系ガスを用い, イオン源内でイオン化する。炭素 ガスがイオン化されたイオン源から直流電压によって引き出 されたビームを基板上へ照射する。コーティングできる面積 が狭小なことや成長速度が遅いなど問題点も多く残る。

この方法から得られる炭素膜は,これまでイオンビームの頭 文字を取ってi-carbonと名付けられていた(4)。この方法は，イ オンの加速エネルギーを大きく可変できるので, 高加速エネル ギー条件を選択することで硬質膜は比較的容易に得られる。

スパッタリング法を有効に活用すると高融点物質や熱分解 しやすい材料の合成に利用でき, 炭素膜の作製にも利用され ている。放電方法, 電極構造, イオン加速方法などによってス パッタリング法は分類される。原料となるターゲット材も複 数設置することが可能で複合材料を作製できる。ターゲット から原料をたたき出すためにプラズマからイオンを生成し, ターゲットへ照射する。このプラズマは, 化学的に不活性な Arガスが通常用いられる。スパッ夕効率を高めるために磁石 を設置したマグネトロンスパッタも成長速度の向上には有効 である。また,イオンビームをターゲットに照射し, DLC膜を 合成する方法も開発されている91。

イオンプレーティング法は, メッキ法よりも密着性や耐摩 耗性に優れた特長があることから有効な手段として開発され たが, 近年は電子材料, 金属, 光学材料への展開が店がってい る。原料をプラズマ状に活性化またはプラズマ中へ導入して イオンや励起種（ラジカルと呼ばれる電気的に中性である が，エネルギーを持っている分子種）を利用して基板上に作
Table 1 Specification of the typical DLC film.

\begin{tabular}{|c|l|}
\hline Refractive index & 2.5 \\
\hline Density & $2.12 \mathrm{~g} \cdot \mathrm{cm}^{-3}$ \\
\hline Electrical resistivity & $2.24 \times 10^{10} \Omega \cdot \mathrm{cm}$ \\
\hline Hydrogen content & $1.35 \times 10^{23} \mathrm{~cm}^{-3}$ \\
\hline Spin density & $4.3 \times 10^{20} \mathrm{~cm}^{-3}$ \\
\hline Hardness & $45 \mathrm{GPa}$ \\
\hline
\end{tabular}

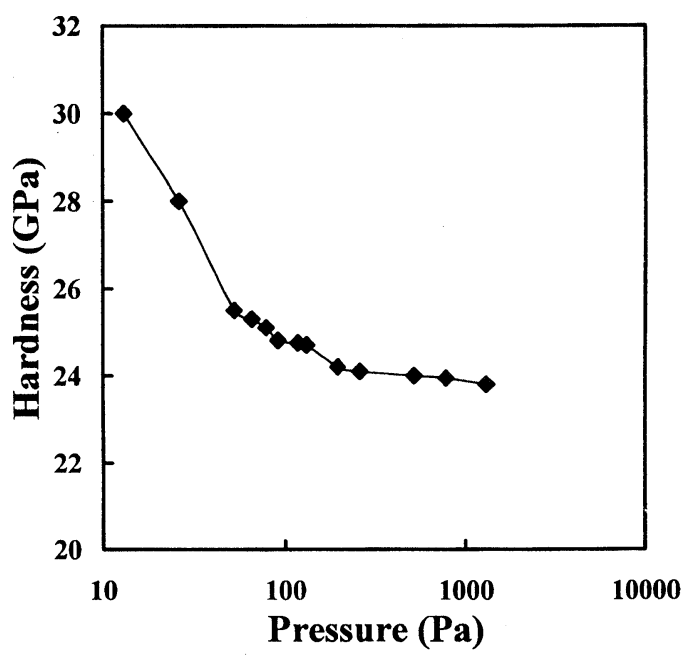

Fig.2 Knoop hardness of the DLC films as a function of the pressure.

製するので反応性ガスを利用した反応性イオンプレーティン グが有効な方法である。プラズマ励起手段は, コイルを用い コイル内に励起種を生成し, 基板に印加された直流電圧によ って引き寄せる。この方法で得られる炭素膜は, 比較的軟質 で, 太陽電池の空材料などの応用が検討されている。

\section{DLC膜の基本物性}

本方法によって得られた典型的なDLC膜の特性をTable 1 に示す。抵抗率, 硬度がダイヤモンドに近い值を取ることが わかる。屈折率に関しても興味深い值で, 光学的分野への応 用も期待される7゙。

高周波プラズマCVD法によって得られるDLC膜の作製時 の圧力に対する膜硬度をFig.2に示す。高分子材では, 母材と しての強度や一部の評価方法に適さないなどの理由により, この基礎特性には, Si基板を用いてDLC膜を作製した結果を 用いた。膜硬度はガス圧力に強く依存しており，低圧力側で 比較的硬い膜が, 高圧力側で軟質な膜が合成できる。これは, 低圧力で大きくなる自己バイアス電圧によって, イオン化さ れた励起種の加速エネルギーが増大し, 膜の硬度に影響を与 えるためである。イオン加速電圧を制御したイオンビーム法 での電圧変化に対しても同様な膜の変化が現われる。

圧力に対する膜の成長速度は, 圧力の上昇に対し単調に増 
加している。これは, 反応容器内のガス分子数に影響してい る。つまり, 高い压力ではプラズマ中に存在する絶対的な励 起種密度が高いことに起因する。絶縁物の厚さに依存して DLC膜の膜質が大きく変化する報告があり, 絶縁物上のDLC 膜を評価する必要がある。そこで, 基板高分子材料（ポリカ ーボネート,ポリウレタン）上に堆積したDLC膜の成長速度 を光学的な評価方法によって調べた。Fig.3にポリカーボネ 一ト（PC）上に製膜したDLC膜の成長速度の関係を示す。 $\mathrm{Si}$ 上に堆積したDLC膜の成長速度とほぼ同一の結果が得られ た。この実験で用いたPC基板の厚さが $1 \mathrm{~mm}$ と極薄いことが, この結果を導いたと考えられる。しかしながら, DLC膜の成 長には, 原料となるプラズマ中のイオンエネルギーが重要な 要因と考えられることから, 母材料の導電性やその厚さが, 得 られるDLC膜の結果に大きく影響すると考えられる。

しゅう動部やコート材としての機械的な応用を考えると， 膜の摩擦係数が重要な要素となる。膜の相対的摩擦係数を原 子間力顕微鏡 $(\mathrm{AFM})$ より得た (Fig.4)。摩擦係数は, 表面 粗さと同様な变化を示し, 高压力側で高くなる。DLC膜の絶 対的な摩擦係数は, $0.05 \sim 0.150$ 範囲と報告されていること から ${ }^{15)}$, 本方法で得られる膜も低圧力で得られる膜は, かなり 摩擦係数の低い膜であると推定される。表面粗さや摩擦係数 の低さは, 接触部での潤滑性㐫用に有效に働く。

Fig.5にAFMの観察結果から得られた膜の厚さに対する表 面粗さを図示する。膜厚は, DLC膜の表面粗さに影響し, 低压 側では膜厚が厚くなると表面粗さが減少し, 高圧側では, 厚さ に伴い増加する8)。しかし, 絶対的な粗さは, nmオーダを示し 通常の応用に際しては充分に緻密な表面状態となっている。 これまでの実験から, 表面粗さは作製時の圧力にも強く依存 する結果が得られている8)。この要因は, 基板ホルダーとして

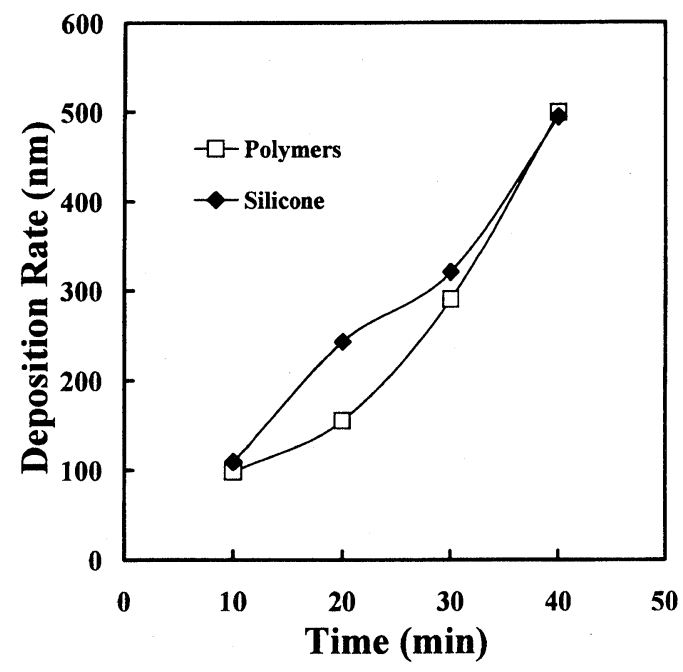

Fig.3 Deposition rates of DLC films produced in Si and polymers.
利用している電極上に発生する直流バイアス電圧に由来する イオンの加速エネルギーによるものと考えられている。

高分子材料上で作製したDLC膜のAFMによる钼察結果を Fig.6に示す。高分子材料上に堆積したDLC膜の表面状態は, $\mathrm{Si}$ 基板に比べると粗くなっている。ポリカーボネート, テフ ロン, ポリウレタン上の表面粗さは, それぞれ11.8, 82.3, $29.7 \mathrm{~nm}$ であった。この違いは，母材の硬度に由来していると 考えられるが, 詳細は今後の検討に委ねられる。

\section{DLC薄膜の生体材料としての可能性}

炭素系材料は, その特性（高硬度, 低摩擦係数, 耐食性, 光透 過性等）が幅広く利用できる点や生体に対する安走性が見込

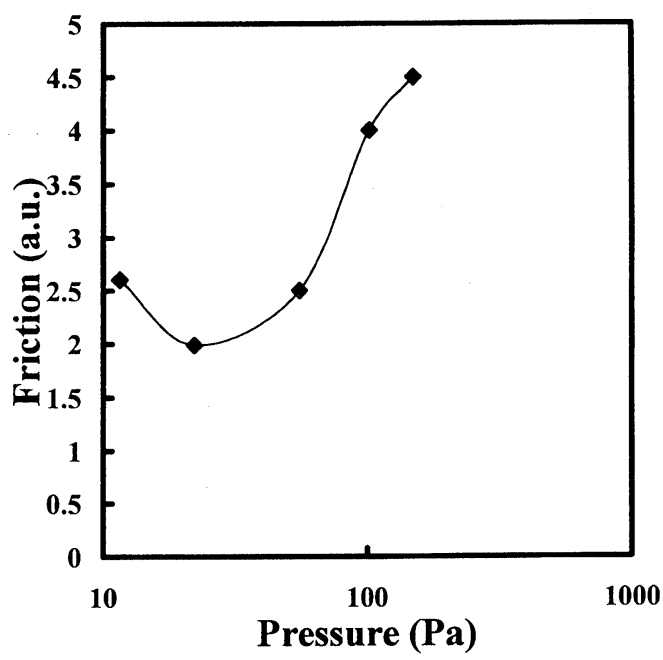

Fig.4 Friction of the DLC films as a function of the pressure.

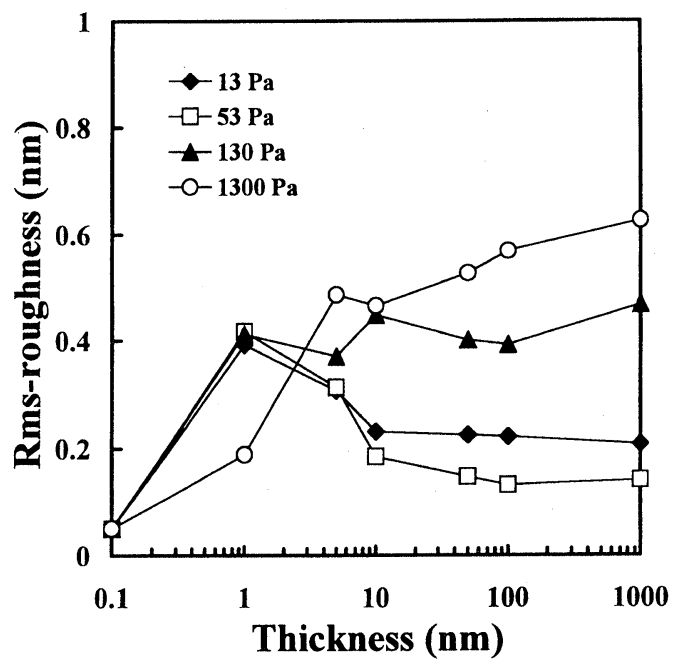

Fig.5 Rms roughness of the DLC films versus thickness. 


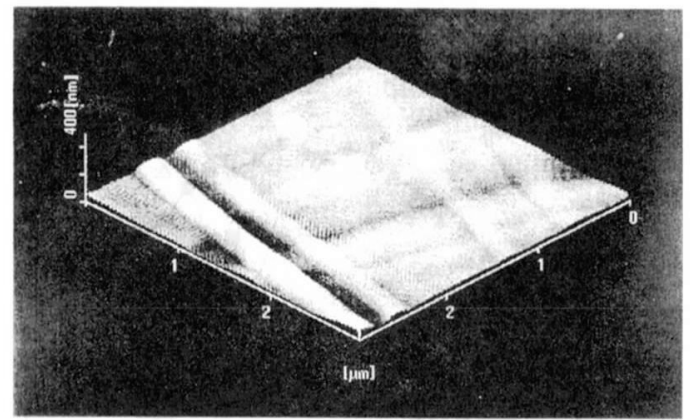

(a)

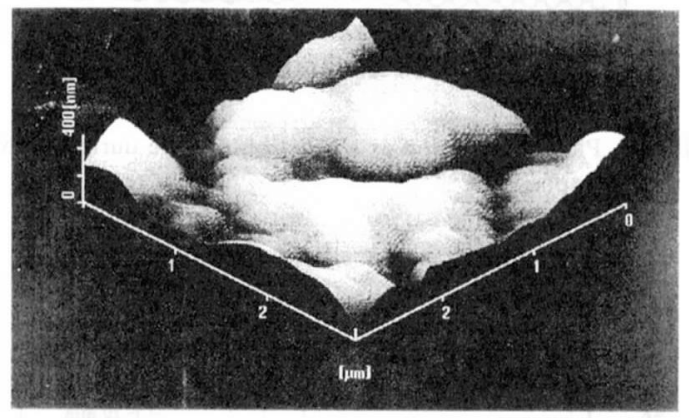

(b)

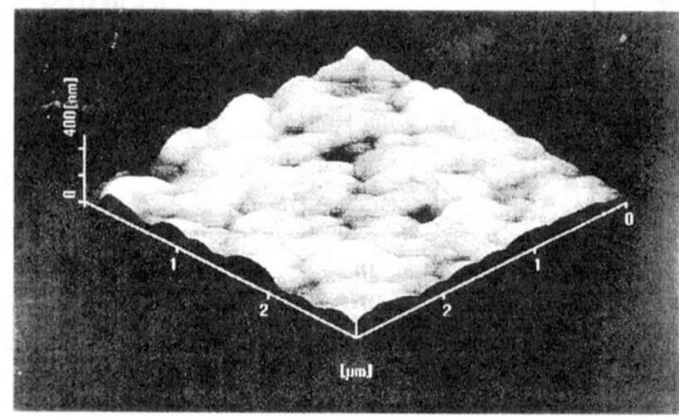

(c)

Fig.6 SEM images of DLC films on several kinds of polymeric materials. (a) polycarbonate (b) teflon (c) polyurethane

まれることから,バイオマテリアルとしての応用が検討され ている。すでに人工心臓の一部に使われているチタン材料上 にDLCコートが施され，実用段階に近づいている16。本節で は, DLC膜のバイオマテリアルとしての適用可能性を検討す る実験を行い, その結果について報告する。

\subsection{DLC膜の水溶液透過性}

一部の高分子材料では長期利用時に溶液が極微量透過して しまう久点が存在する。そこで,バイオマテリアルとして広 く活用されているポリウレタン (PU) 基板上へDLCコーテ イングを実施し, 溶液の透過性について検討した。実験には

Fig.7に示す溶液の透過性を評価する実験装置を開発し使用 した。実験の際に二つのセルを持つ装置の中間位置に実験每 にPUまたはDLC膜コートしたPUを装着する。それぞれのセ

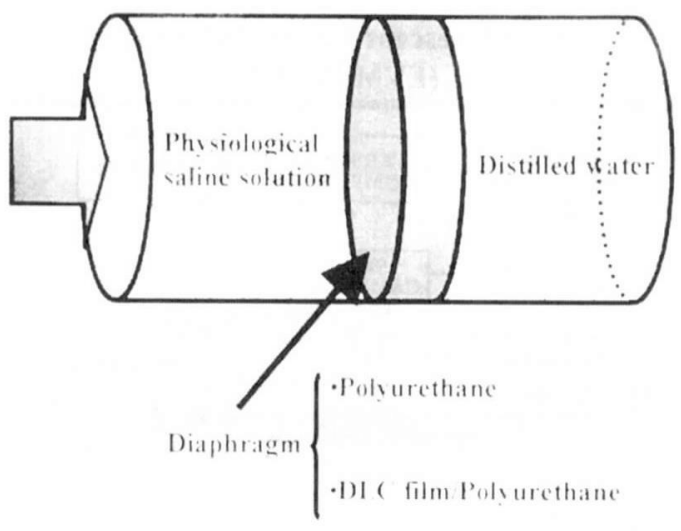

Fig.7 Schematic illustration of the experimental system for estimation of diffusion through diaphragm.

Table 2 Concentration of $\mathrm{Na}$ ion diffusion through the diaphragm.

\begin{tabular}{|c|c|}
\hline Diaphragm & Concentration \\
\hline Polyurethane (PU) & $32.8 \mathrm{ppm}$ \\
\hline DLC/PU (deposited at $10 \mathrm{pa})$ & $30.2 \mathrm{ppm}$ \\
\hline DLC/PU (deposited at $30 \mathrm{pa})$ & $1.13 \mathrm{ppb}$ \\
\hline DLC/PU (deposited at $10 \mathrm{pa})$ & $0.76 \mathrm{ppb}$ \\
\hline DLC/PU (deposited at $30 \mathrm{pa})$ & $0.85 \mathrm{ppb}$ \\
\hline Distilled water & $1.25 \mathrm{ppb}$ \\
\hline
\end{tabular}

ルには, 生理食塩水および蒸留水を充填し, 生理食塩水側から $2 \mathrm{~kg} / \mathrm{mm}^{2}$ の静圧力在付加する。一定時間保持した後, 蒸留水 中のNaイオン濃度を質量分析器により測定した。結果を Table 2に示す。実験前の蒸留水中のNaイオン濃度は, 数ppb オーダであった。PUのみを両セル間に固定した場合は, 数十 ppmオーダの值が検出された。(約 $10^{4}$ の濃度変化が現れた。） これは, PUシートを通じて生理食塩水が透過していることを 物語っており, 圧力に変化がある部位での溶液保持にはPUが 不向きであることを示唆している。一方, PU上にDLC膜をコ ーティングした試料を両セル間に置き換えたところ, 蒸留水 中のNaイオンの濃度はppbオーダの值が得られた。この值は, 蒸留水中のNaイオン濃度に匹敵し, 生理食塭水の透過がDLC 膜コーティンクによって阻止されていることを示寸結果とな った。

現在, 血液循環機能を補助することを目的とした人工心臓 は, 開発が進み実用可能な域にある。しかし, 拍動流型人工心 蔵では,ドライブ側にあるシリコーンオイルが年間約数 $\mathrm{cc}$ 程 度, PUダイヤフラムを通して血液側に透過し, 重大な問題を引 き起こす。PUダイヤフラム上へのDLCコーティングが実用 化すれば,このような問題の解決に役立つことが考えられる。

\subsection{DLC膜の抗血栓性}

DLC膜をバイオマテリアルとして応用するためには, 生体 に対する反応圭評価する必要がある。そこで, 血液反応の基 
Epifluorescent Video Microscopy (EVM) System

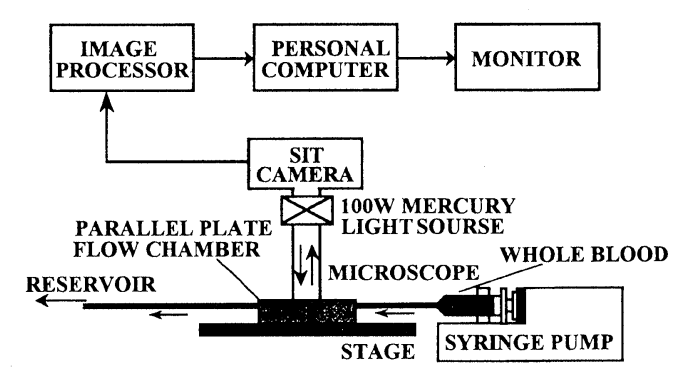

Fig.8 Epifluorescent video microscopy (EVM) system for evaluation of blood compatibility.

礎特性として抗血栓性について検討した。評何実験の装置 (EVM) 配置をFig.8に示す。高分子母材（ポリカーボネー ト：PC）上にDLCコーティングした試料を真空チャックで 試料ホルダーに固定する。あらかじめ薬品（Mepacrine \& Heparin）により制御された人血を試料（種々のDLC膜およ び比較用のTecoflex，抗血栓材を塗布してある試料）表面に 触れるよう流入する。PCの抗血栓性は, 非常に悪いのでここ では罒に掲載していない。この際，血检が表面上に付着する と上部にあるカメラによりin-situで検出される構造になって いる。実験時間に対する表面に付着した血栓の面積率によっ て抗血栓性を推定した17)。DLC膜の作製条件は，圧力を一定 にし,作製時間を変化した試料を用いた。

Fig.9に実験結果を示す。DLC膜に対する付着率は, 比較用 試料の中間に位置する。なかでも，血栓を制御するためにPC 表面に薬品が塗布された試料に匹敵するDLC膜があること が判明した。低付着率での関係を比較するために，この図を 付着率が1％未满で拡大した $($ Fig.10)。15分以上の時間経過 では，薬品により血栓性が押さえられた試料 (HEMA/St) よ り，DLC膜コーティング試料の付着率が低いことがわかる。 これは, 長期間使用するバイオマテリアルには必要不可欠な 特性であり，血栓に関する性質が極めて良好であると言える。

実駼後の表面状態を走査型電子顕微鏡（SEM）によって 観察した（Fig.11）。DLC膜がない場合は, 全体に付着物が見 られ，実験結果を反映している。一方，DLC膜をコーティング した試料では, 付着物がほとんと観察されず, 表面が実験前後 でほとんど変化していないことが分かった。

次に, DLC膜の作製条件に対する抗血栓性の評価を行った。 25分経過時の付着面積率を作製条件である堆積時間で図示し た (Fig.12)。血栓付着率は, 堆積時間とともに増加すること がわかる。この差異を検討するためにXPSによる組成分析を 行った。膜組成は, 作製時間15分の試料では炭素濃度が高く, 堆積時間とともに低下する。しかし, 20分以降の試料とは明 確な違いは見あたらず, 組成分析の結果だけで判断はできな

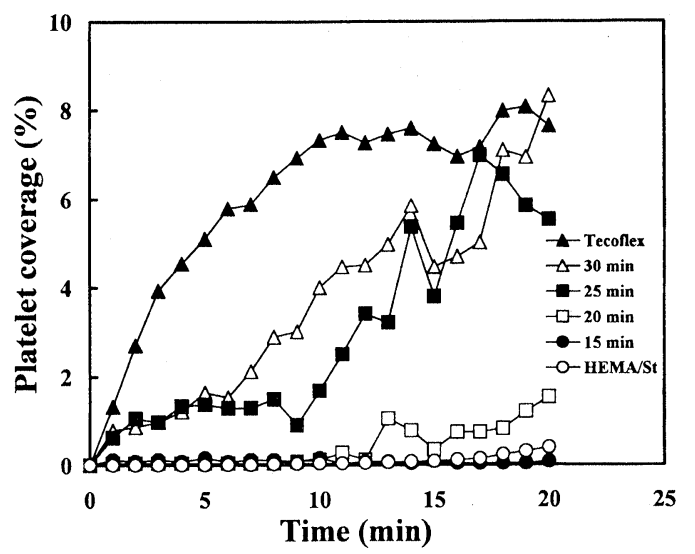

Fig.9 Platelet adhesion as a function of time during EVM experiment.

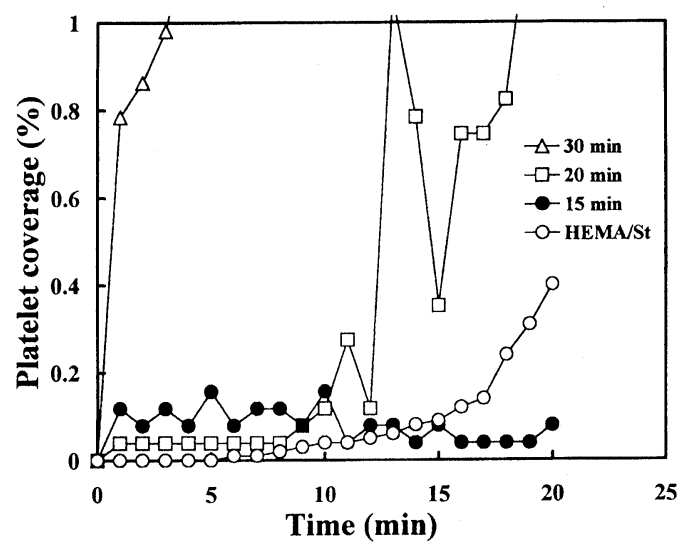

Fig.10 The expanded sectional view of Fig.9.

い。DLC膜の表面荒さは, 膜の厚さに大き〈依存する81,18)。 そこで,一つの可能性としては, 膜厚に対して表面の平滑性が 変化し, 表面荒さの違いが抗血栓性の変化として現れたと考 えられる。

\section{5. まとめ}

バイオマテリアルの開発には, 素材の基礎特性評価から始ま り,動物実験など非常に複雑な判断が必要になっている。いか なる素材が生体適合性を持つか? 毒性はないか? 血液との反 応性は良いか?など多くの判断基準が必要であり,すべてを満 足する新素材の開発は極めて難しいと言わざるを得ない。視 点を変えてみると, 本来強度や粘性などの機械的特性を必要と する部位には, 既存の材料を用い, 生体表面部(つまり, 直に生 体と触れる場所）に生体適合性が良い物質をコーティングす ることで問題の解消を図る可能性があると思われる。

これまで, DLC膜コーティングは電子材料として適用性が 


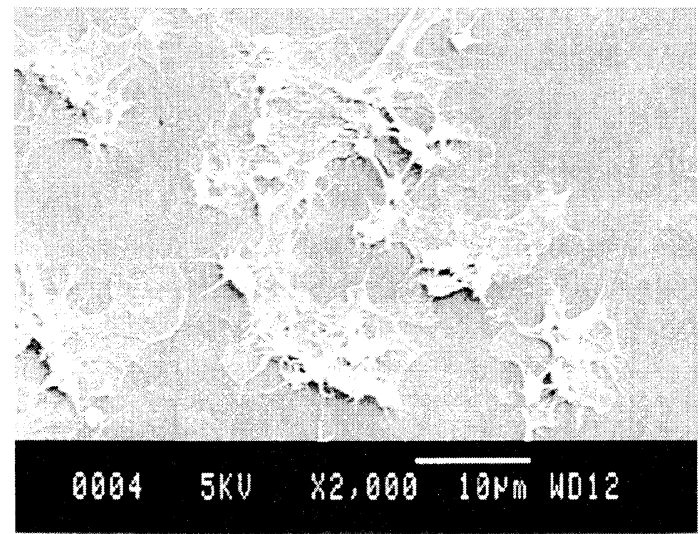

(a) polycarbonate

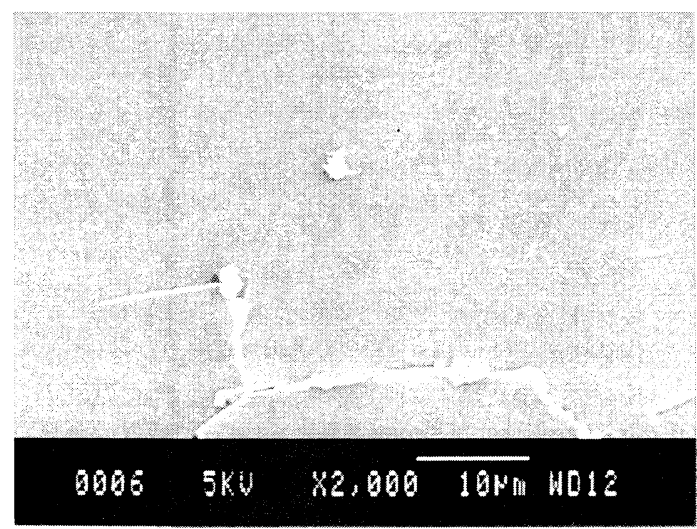

(b) polycarbonate-DLC

Fig.11 The surfaces of polycarbonate and DLC film deposited on polycarbonate after EVM experiment. (a) polycarbonate (b) DLC/polycarbonate

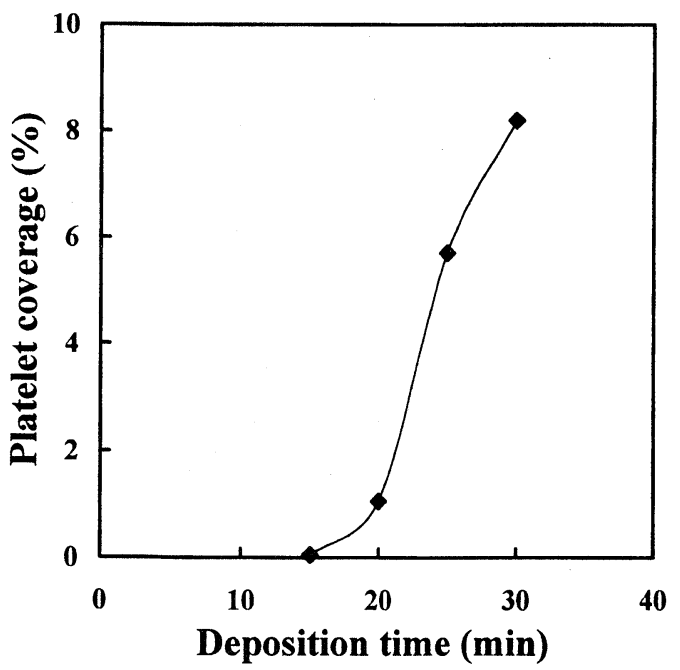

Fig.12 Platelet coverage of EVM experiment as a function of DLC deposition time.
模索されてきたが, 生体に優しい材料としての可能性が示唆 されている現在, 新たなバイオマテリアルとして検討が進み 始めた。しかし, 医用材料としてのDLC膜応用は未知の部分 が多く, 研究も緒についたばかりであるので, 今後の開発と更 なる発展性を切り拓くことが求吼ている。応用に際して のさまざまな問題（生体中各部位での耐久性など）を解決す るために, 医学のみならず工学分野の研究協力が不可久とな るであろう。

\section{謝 辞}

本研究の成果の一部は, 国立循環器病センターおよびテル モ株式会社との共同研究を含んでいる。ここに, その謝意を 表します。

\section{文 献}

1) S. Itoh, S. Fujiwara, New Diamond, 44 (1997) 2-5 [in Japanese]

2) 日本機械学会編：「生体材料学」, オーム社

3）中林 宣男, 石原 一彦, 岩崎 泰彦：「バイオマテリ アル」,コロナ社

4）筏 義人：「生体材料学」基礎生体工学講座，産業図 書, 東京

5) S. Matsumoto, Y. Sato, M. Kamo and N. Setaka, Jpn. J. Appl. Phys., 21 (1982) L183.

6) K. Kobayashi N. Mutsukura, and Y. Machi, J. Appl. Phys., 59 (1986) 910.

7) K. Kobayashi, N. Mutsukura and Y. Machi, Thin Solid Films, 158 (1988) 233

8) K. Hirakuri, T. Minorikawa, G. Friedbacher and M. Grasserbauer, Thin Solid Films, 302 (1997) 5-11.

9) M. Kitabatake and K. Wasa, J.Appl.Phys., 58 (1985) 1693-1695.

10) K. Kuwayama, New Diamond, 42 (1996) 20-23 [in Japanese].

11) H. Hosotani, New Diamond, 22 (1991) 21-25 [in Japanese].

12) O. Sugiyama, New Diamond, 48 (1998) 19-23 [in Japanese].

13) K. Hirakuri, Jinkouzouki, 28 (1999) 612-617 [in Japanese

14) S. Aisenberg and R. W. Chabot, J.Appl.Phys., 42 (1971) 2953-2958.

15) A. Tanaka, New Diamond, 43 (1996) 12-17 [in Japanese].

16) K. Yamazaki, Nihonikakikai, 100 (1997) 731-735 [in Japanese].

17) A. Alanazi, T. Noguchi, T. Kido, C. Nojiri, Y. Komatsu, K. Hirakuri, A. Funakubo, K. Sakai and Y. Fukui : American Society for Artificial Internal Organs 45th abstract, (1999).

18) A. Alanazi, K. Hirakuri and G. Friedbacher, Vacuum, 51 (1998) 363. 